\title{
A Comparative Study on the Impact of Avu and Ihie Dumpsites on Soil Quality in Southeastern Nigeria
}

\author{
Amadi A. N. ${ }^{1,{ }^{*}}$, Olasehinde P. I. ${ }^{1}$, Okosun E. A. ${ }^{1}$, Okoye N. O. $^{1}$, Okunlola I. A. ${ }^{1}$, Alkali, Y. B. ${ }^{1}$, \\ Dan-Hassan M. A. ${ }^{2}$ \\ ${ }^{1}$ Department of Geology, Federal University of Technology, Minna \\ ${ }^{2}$ Rural Water Supply and Sanitation Department, FCT Water Board, Garki, Abuja
}

\begin{abstract}
The effects of leachate from unlined open waste dumps on the soil and aquifer system in Avu and Ihie area of Southeastern Nigeria was investigated in this study. The soil $\mathrm{pH}$ in both dumpsites is very low and it is a reflection of the microbial action in the process of decomposition of waste materials as well as the acid-rain formation via gas flaring. It was established that the mean concentrations of manganese, lead, iron and bacteria count were higher in Avu dumpsite soil while the other parameters are higher at Ihie dumpsite soil. The concentrations of all the parameters analyzed were below the crustal abundance of the respective elements except cadmium. The high concentration of cadmium can be attributed to the decay of abandoned electric batteries and other electrical parts. The soil samples collected far away from the dumpsites have lower concentrations compared to the samples collected in the vicinity of the dumpsites suggesting a possible soil contamination via leachate from the nearby dumpsites. The graphs of sieve and correlation analyses from the dumpsites were very similar and this implies similarity in wastes materials and geohistory. Construction of future dumpsites in the area should follow the prescribed design of a modern sanitary landfill system that quarantee protection to the soil and aquifer materials.
\end{abstract}

Keywords Comparative Analysis, Dumpsites, Impacts, Soil, Southeastern Nigeria

\section{Introduction}

Pollution of soil by leachate from surrounding municipal waste dumps has been recognized for a long time (Banar et al., 2006; Alloway, 1990; Tahri et al., 2005; Lin et al., 2002; Amadi et al., 2010). In Nigeria, like in other developing countries, open dump is the only available option for solid waste disposal in the cities. Chopra et al., (2009) described waste dumps practices as the disposal of solid waste by infilling depressions on land. The depressions into which solid wastes are often dumped include valleys and excavations. The negligence of the effects of unlined waste dumps on the host soil and underlying shallow aquifers in southeastern Nigeria characterized by largely unconfined, porous and high permeable aquiferous system is worrisome.

Studies have shown that soil and groundwater system can be polluted due to poorly designed waste disposal facilities, leakage from underground storage tanks and agricultural wastes. Soil and groundwater acidification and nitrification have been linked to waste dumps (Bacud et al., 1994) as well as microbial contamination of soil and groundwater system (Awomeso et al., 2010). Sia Su (2008) attributed cancer,

* Corresponding author:

geoama76@gmail.com (Amadi, A. N.)

Published online at http://journal.sapub.org/ chemistry

Copyright (C) 2012 Scientific \& Academic Publishing. All Rights Reserved heart diseases and teratogenic abnormalities to groundwater contamination via leachate from waste dumps. Increase in population and rapid expansion of cities has resulted to generation of huge waste and they manner these wastes are disposed constitutes serious health and environmental problems.

The impact of Avu and Ihie waste dumps (Plates 1 and 2) on the host soil and underlying shallow aquifer system was investigated in this study. Modern sanitary landfill that will protect the aquifer system in area from leachate contamination by waste dumps was proposed. The vulnerability of the soil unit in the region adjudged from its hydraulic properties (porosity and permeability) necessitated this study.

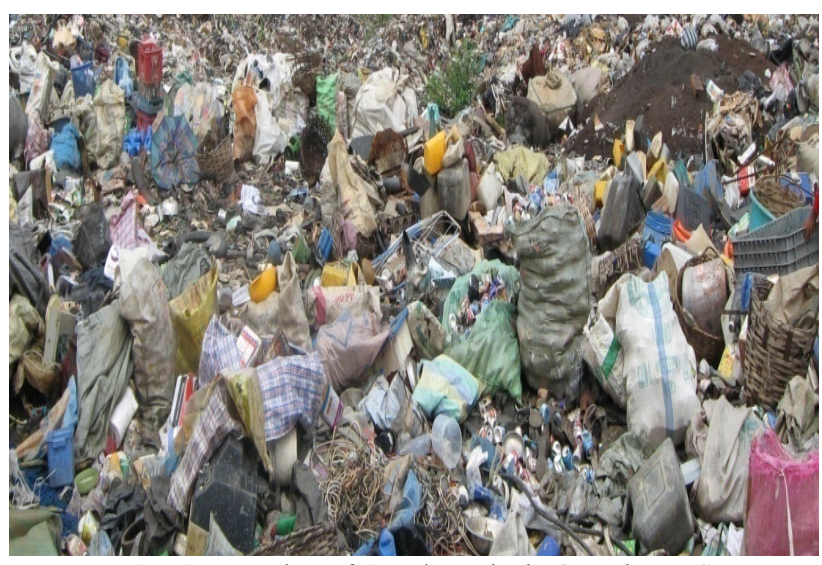

Plate 1. An overview of Avu dumpsite in Owerri, Imo State 


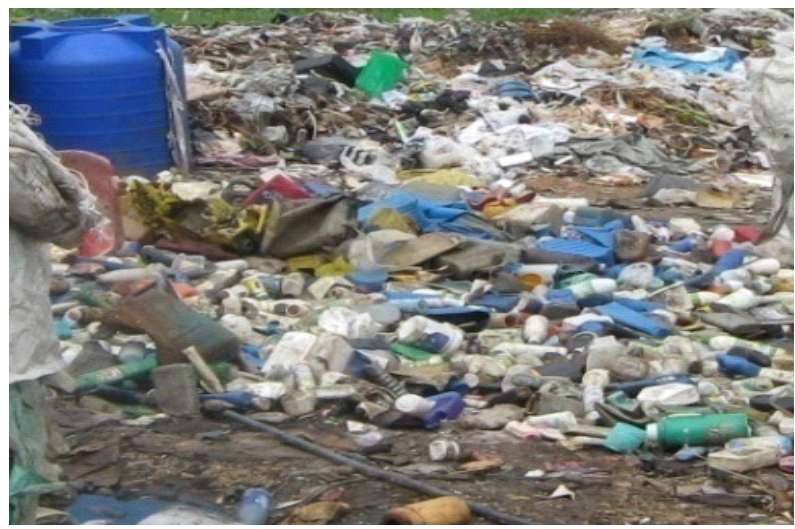

Plate 2. Front-view of Ihie dumpsite in Aba, Abia State

\section{Study Area Description}

Avu dumpsite is located in Owerri, Imo State, along Owerri - Port-Harcourt road while Ihie dumpsite is in Aba, Abia State, along Aba - Port-Harcourt express way. The dumpsites are in southeastern Nigeria, between Longitudes $6^{\circ} 20^{\mathrm{I}} \mathrm{E}$ to $7^{\circ} 50^{\mathrm{I}} \mathrm{E}$ of the Greenwich Meridian and latitudes $5^{\circ} 20^{\mathrm{I}} \mathrm{N}$ to $6^{\circ} 50^{\mathrm{I}} \mathrm{N}$ of the Equator (Fig.1). The area is low lying with good road network and is drained by Imo, Kwa-Ibo and Bonny rivers and their tributary.

\section{Physiography of the Study Area}

The prevalent climatic condition in the area is marked by two main regimes: the rainy and the dry seasons. The rainy season is from April to October during which the temperature varies from $25^{\circ} \mathrm{C}$ to $29^{\circ} \mathrm{C}$, and this season is associated with the prevalent moisture-laden south-west trade wind from the Atlantic Ocean. The wet season is also characterized by double maximum rainfall during which the first peak occur in July and the second occurs in September with a mean annual rainfall of $2152 \mathrm{~mm}$ (Ezeigbo, 1990). The dry season starts in November, when the dry continental northeastern wind blows from the Mediterranean Sea across the Sahara desert and Samarian desert and down to the southern part of Nigeria. Due to vagaries of weather, the August break sometimes occurs in July or early September. Humidity is usually low and clouds are absent, during the dry season. The effect of the harsh north easterly wind, also called Harmattan, is felt within the period. The average monthly temperatures are high throughout the year. A mean annual temperature of $31^{\circ} \mathrm{C}$ is typical of the area (Ezeigbo, 1990). The area lies within the tropical rain forest belt of Nigeria. The natural vegetation in greater part of the area had been replaced by derived savanna grassland interspersed with oil palm trees.

\section{Geology and Hydrogeology of the Area}

The study area is outcropped by the Oligocene Benin Formation which is known as the 'coastal plain-sand' (Fig.1). It consists mainly of sands, sandstone and gravel with clays occurring in lenses. The sands and sandstones ranges from fine to coarse grained and is largely unconfined, with thickness ranging from $2.0 \mathrm{~m}$ to $2100.0 \mathrm{~m}$ (Avbovbo, 1978). The sediments represent upper deltaic plain deposits. The Benin Formation is composed mainly of high resistant fresh water-bearing continental sands and gravels with minor clay intercalations (Onyeagocha, 1980). The environment of deposition is partly lagoonal and partly fluvio- lacustrine/deltaic (Reyment, 1965). The formation which dips south westward starts as a thin edge layer at its contact with the Ogwashi - Asaba Formation in the northern part of the area, and thickens southwards to about $1000.0 \mathrm{~m}$ in Owerri area and $1200.0 \mathrm{~m}$ in Aba area (Ibe, et al., 1992). The sandy unit which constitutes about $95 \%$ of the rock in the area is composed of over 96\% of quartz (Onyeagocha, 1980.

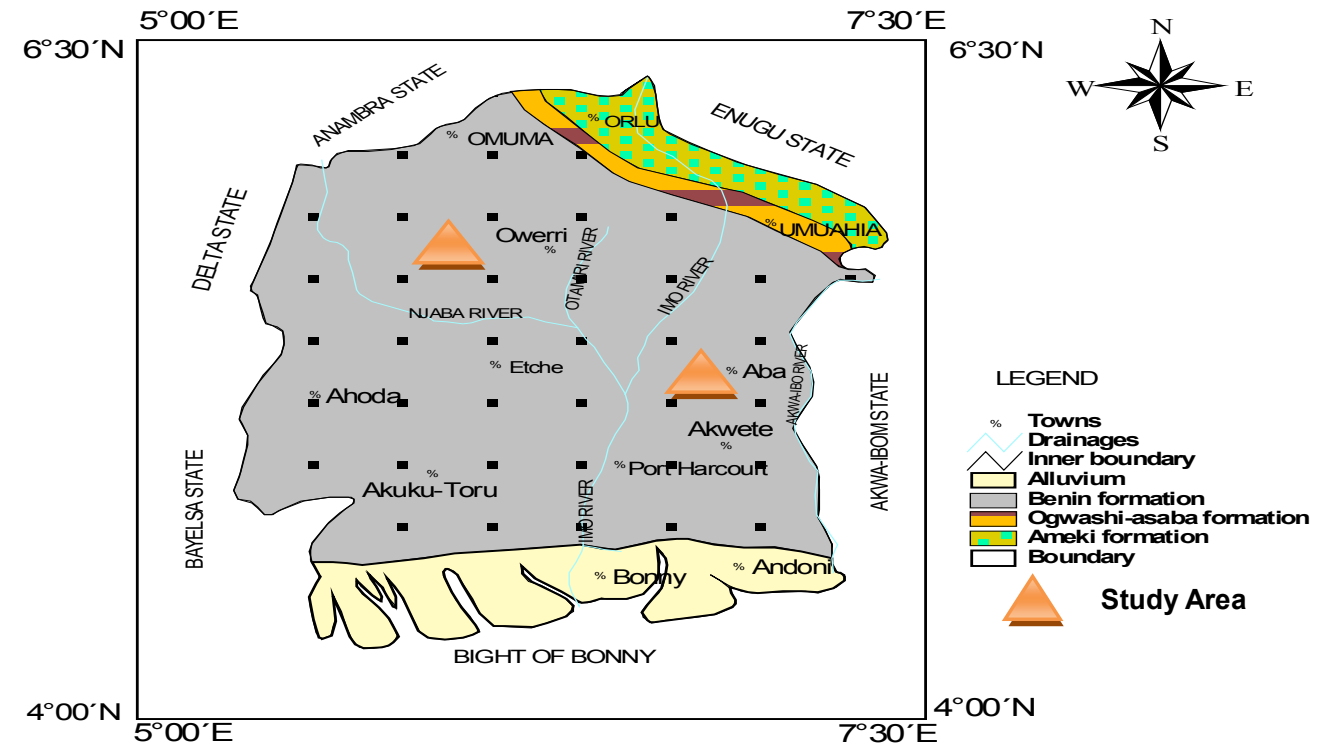

Figure 1. Geology map of the study Area (Source: Amadi, 2010) 
Table 1. Stratigraphic Units of the Niger Delta Basin (After Short and Stauble, 1967)

\begin{tabular}{|c|c|c|}
\hline Outcropping Units & Subsurface Units & Present-day Equivalents \\
\hline Benin Formation & Benin Formation & Continental (fluviatile) deposits mainly sandstones \\
\hline Ogwashi -Asaba Formation Ameki Formation & Agbada Formation & Mixed continental brackish water and marine deposits, sandstones and clays \\
\hline Imo Shales & Akata Formation & Marine deposits, mainly clays \\
\hline
\end{tabular}

\section{Stratigraphy of the Area}

The stratigraphy of southeastern Nigeria has been studied in details by Uma and Egboka (1985). The Stratigraphic succession of rocks in the study area (Table 1) consists of Imo-Shale-Formation, being the oldest formation and followed by Ameki Formation, Ogwashi-Asaba Formation while the youngest is the Benin Formation (Uma and Egboka, 1985). The coastal plain sand belonging to the Benin Formation extends to a considerable depth in the area and with good hydraulic properties for groundwater development. The formation consists predominantly of very thick coastal sand, sandstone, clays and sandy clays occur in lenses. The Benin Formation is in part cross-stratified with the forset beds alternating between coarse and fine-grained sands. Petrographic study on several thin sections (Onyeagocha, 1980) shows that quartz makes up more than $95 \%$ of all grains. Groundwater occurs abundantly in the coastal plain sands (Benin Formation) and the static water level (SWL) ranges from $8.0-65.0$ meters depending on the location and the time of the year. The Benin Formation is a good aquifer with an average annual replenishment of about 2.8 billion cubic meters per year (Onyegocha, 1980). In most areas, the sandy components form more than $90 \%$ of the sequence of the layers therefore permeability, transmissivity and storage coefficient are very high.

\section{Materials and Method}

\section{Soil Sampling}

A total of 40 soil samples each were collected from the vicinity Avu and Ihie dumpsites between 1.0 - 2.5 meters depth while additional 4 samples at the same depth range was collected far away from each of the dumpsites, to serves as control samples. Sampling tools were washed with water and dried before the next sample was collected. The samples were collected once every month for 4 months during rainy season from June to September, 2010.

\section{Laboratory Analysis}

The soil samples were air-dried in the laboratory at room temperature, grounded to fine mixture using pestle and mortar before sieved under $2 \mathrm{~mm}$ mesh. The samples were labeled appropriately, stored in sealed polythene bags and transported to the laboratory for digestion and analysis. The soil samples were digested in a mixture concentrated nitric acid $\left(\mathrm{NHO}_{3}\right)$, concentrated hydrochloric acid $(\mathrm{HCl})$ and $27.5 \%$ hydrogen peroxide $\left(\mathrm{H}_{2} \mathrm{O}_{2}\right)$ according to the USEPA method 3050B for the analysis of heavy metals and major ions (USEPA, 1996). The $\mathrm{pH}$ measurement of the aqueous suspension 1:5 (w/v) of the $<2 \mathrm{~mm}$ fraction of the soil was performed. The $\mathrm{pH}$ was measured with Consort 2000 $\mathrm{pH}-$ meter equipped with a combined $\mathrm{pH}$ electrode. Conductivity meter and filter membrane method were used for the determination of conductivity and bacteria count respectively. The distilled water used for the preparation of the suspension had been previously boiled and cooled and the sample for determination of bacteria count was incubated for at least 24 hours.

The determination of heavy metals $(\mathrm{Cu}, \mathrm{Zn}, \mathrm{Mn}, \mathrm{Cd}, \mathrm{Pb}$ and $\mathrm{Fe}$ ) was made using the inductively coupled plasma atomic emission spectrometer, ICP-AES, with simultaneous detection Optima 5300 DV (Perkin Elmer), with axial and radial dual vision, while for the determination of major ions, the ELAN DRC II (Perkin Elmer) inductively coupled plasma atomic emission spectrometer, ICP-AES was used.

\section{Results}

The average concentration of the parameters analyzed from the two dumpsites and the crustal abundance of elements as adopted from Dineley et al., (1976) are contained in Table 1. The particle size distribution curve of soil samples from Avu and Ihie dumpsites are illustrated in Figures 2 and 3 . Bar charts showing the mean concentration of the parameter analyzed and the crustal abundance of the elements are shown in figures 4 and 5 while graph of the concentration versus elements in (ppm) is summarized in figure 6. The correlation of the analysis carried out on soil samples from the two dumpsites are illustrated in figures 7 and 8 while the design of a modern sanitary landfill that will quarantee protection to the soil materials is shown in figure 9 .

\section{Discussion}

In order to determine the textural characteristics of the soil where these refuse dumps are domiciled, which invariably influences the rate of leachate migration, soil samples from both dumpsites were subjected to sieve analysis. The results of the sieve analysis are quite similar and the dominant formation was sand (Figures 2 and 3). This agrees with the findings of many authors (Reyment, 1965; (Avbovbo, 1978; Onyeagocha, 1980; (Uma and Egboka, 1985) regarding the geology and hydrogeology of the area. The sandy formation is porous and permeable and this implies that plume from dumpsites will migrate easily into the unconfined shallow aquifer to contaminate the groundwater system. According to Uma (1989), the average linear groundwater flow in the 
area is approximately $400 \mathrm{~m} / \mathrm{yr}$ while leachate moves at about $6 \mathrm{~km}$ away from its source in every 15 years interval. These findings suggest that soil/aquifer contamination via dumpsites plume is inevitable on the long-run due to accumulation effect. Although the contamination is localized at the top-soil, the sub-soil which is uncontaminated presently may be polluted in future if the dumping of refuse persists at the dumpsites because of the vulnerability of the soil formations, since it lacks the capacity to impede downward migration of leachate (Amadi, 2011).

A total of 15 soil quality parameters (Copper, Zinc, Manganese, Lead, Iron, Sodium, Potassium, Calcium, Chlorine, Fluorine, $\mathrm{pH}$, Temperature, Conductivity and Bacteria count) were used for this study. The mean concentration of manganese, lead, iron, $\mathrm{pH}$ and bacteria count were found to be higher in Avu dumpsite soil while the other parameters are higher at Ihie dumpsite soil (Table 2, Fig. 4). The concentration of all the parameters analyzed is far below the crustal abundance of the individual elements concerned except cadmium (Figures 5 and 6). The high concentration of cadmium may be due to the decay of abandoned electric batteries and other electronic components (Mull, 2005). The thickness of lateritic sand (overburden) is higher in Owerri and decreases southwards towards Aba area. Iron is responsible for the reddish-brown colouration in laterites and the leaching of iron oxide is a function of $\mathrm{pH}$. The low $\mathrm{pH}$ in the region could be attributed to acid-rain caused by long-term gas flaring in the region, and has also increase the temperature in the area. The dumping of human and animal excreta (faeces) in the area is responsible for the enrichment of the soil with Bacteria such as total coliform and E. coli and it is an indication of poor sanitary situation in the area (Tijani,
2004). The enrichment of the soil with manganese and lead may be attributed the various human activities going on in the area. The high concentration of the major ions in Ihie dumpsite soil may be linked to its interaction with groundwater that are of marine origin and this explains why the conductivity was also high, because the presence of this ion initiates conductivity of the medium. High copper and zinc concentration are coming from the decomposition of electrical materials, roofing sheets, cooking utensils, alloys, electroplating and chemical effluents (Odero et al., 2000).

Table 2. Summary of mean concentration of elements of soil samples from Avu and Thie Dumpsites and their corresponding crustal abundance (Adopted from Dineley et al., 1976)

\begin{tabular}{|c|c|c|c|}
\hline Parameters $(\mathrm{ppm})$ & Avu & Ihie & $\begin{array}{c}\text { Crustal Abundance } \\
(\mathrm{ppm})\end{array}$ \\
\hline Copper & 21.00 & 33.50 & 70.00 \\
\hline Zinc & 78.20 & 96.55 & 132.00 \\
\hline Manganese & 27.14 & 18.20 & 1000.00 \\
\hline Cadmium & 0.18 & 0.21 & 0.15 \\
\hline Lead & 12.50 & 10.80 & 16.00 \\
\hline Iron & 239.38 & 214.64 & 50000.00 \\
\hline Sodium & 410.67 & 435.27 & 28300.00 \\
\hline Potassium & 110.45 & 143.73 & 25900.00 \\
\hline Calcium & 98.00 & 124.00 & 36300.00 \\
\hline Chlorine & 355.00 & 400.00 & 314.00 \\
\hline Fluorine & 23.00 & 41.00 & 900.00 \\
\hline Ph & 5.10 & 4.82 & - \\
\hline Temperature $\left({ }^{\circ} \mathrm{C}\right)$ & 29.00 & 30.00 & - \\
\hline Conductivity $(\mu \mathrm{s} / \mathrm{cm})$ & 200.00 & 186.00 & - \\
\hline Bacteria Count $(\mathrm{cfu} / \mathrm{mg})$ & 20.86 & 18.00 & - \\
\hline
\end{tabular}

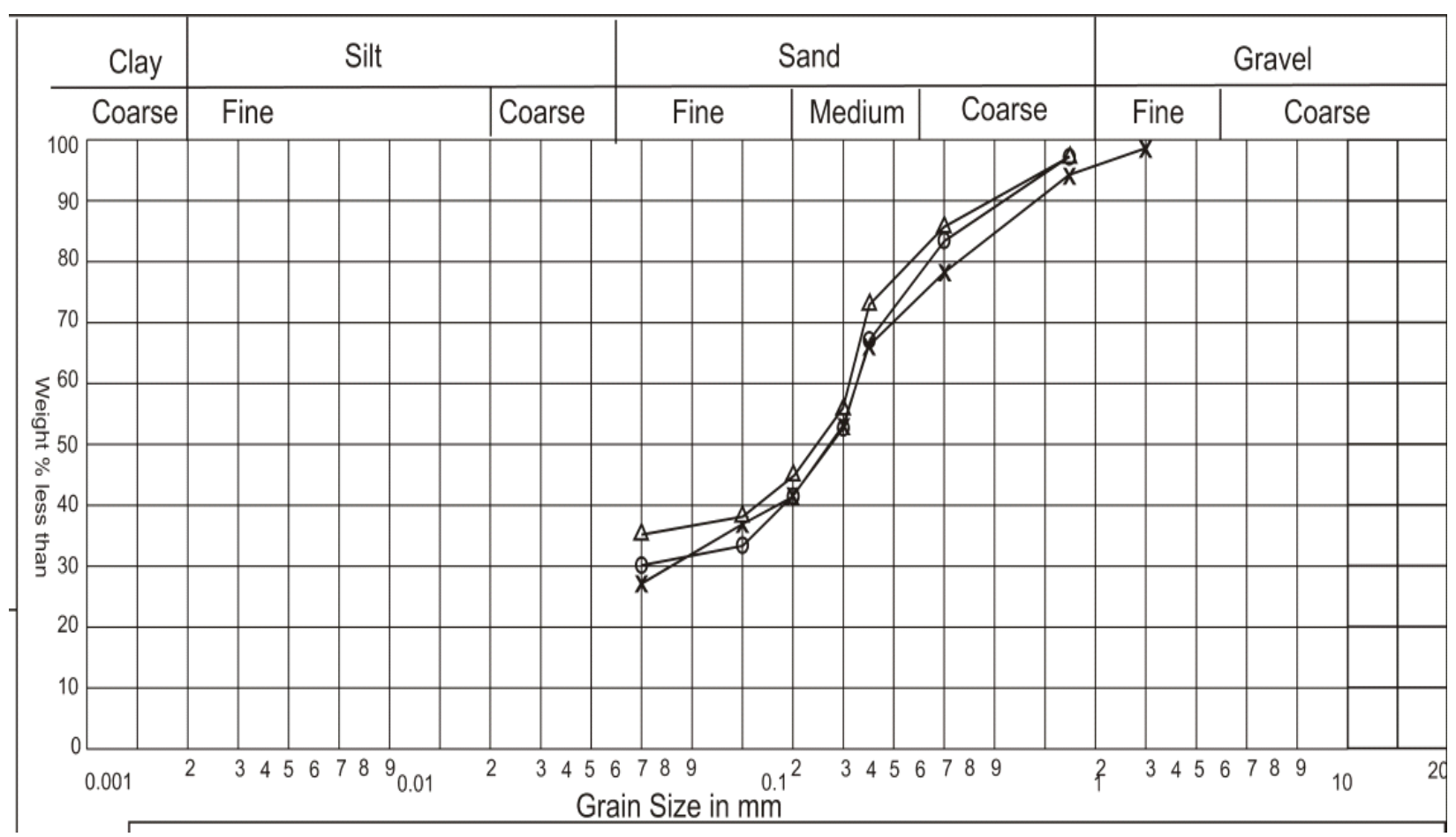

Figure 2. Particle size distribution curve for Avu dumpsite soil 


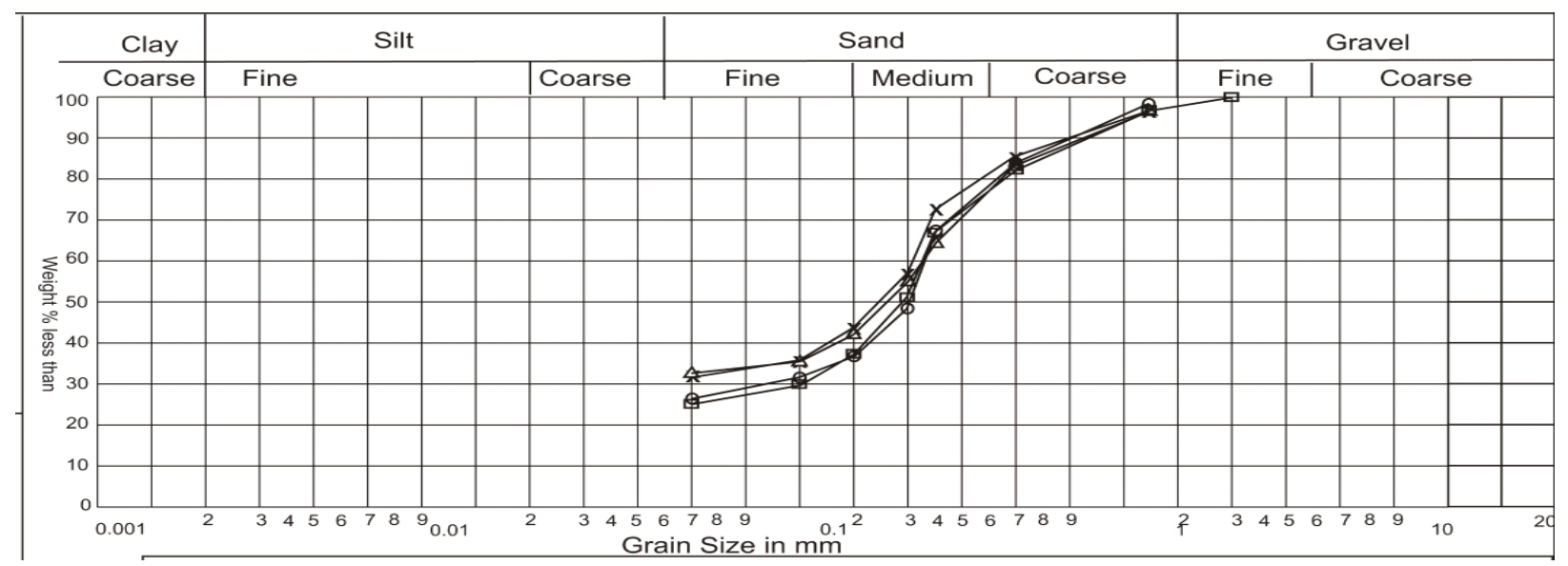

Figure 3. Particle size distribution curve for Ihie dumpsite

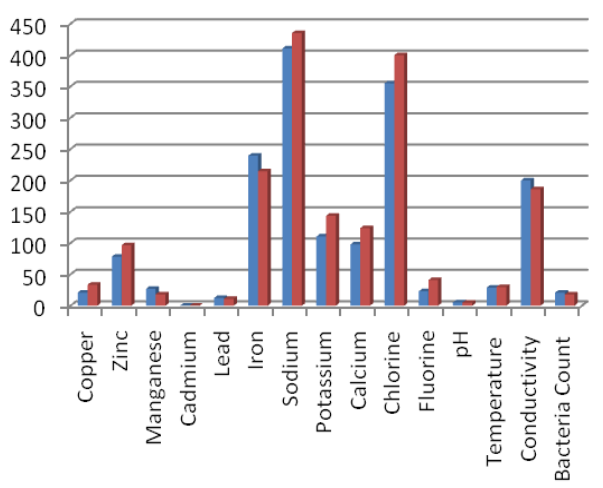

Figure 4. A bar chart showing the mean concentration of the parameter analyzed

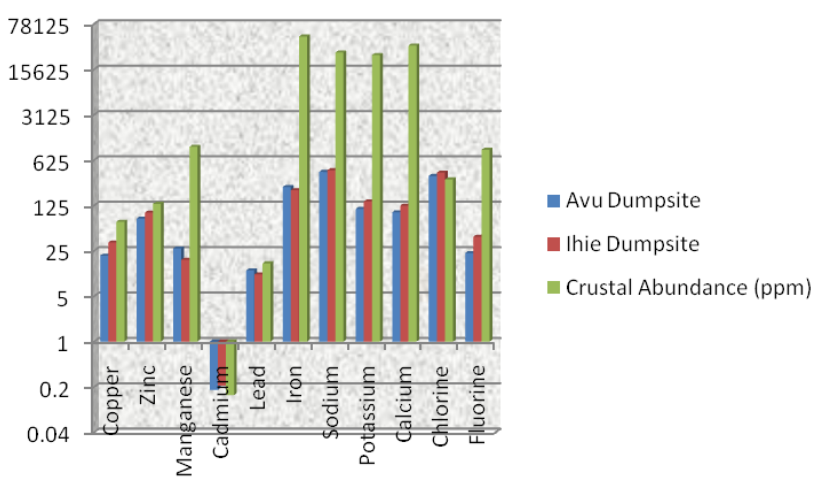

Figure 5. A bar chart showing the mean concentration of the elements analyzed and their respective crustal abundance

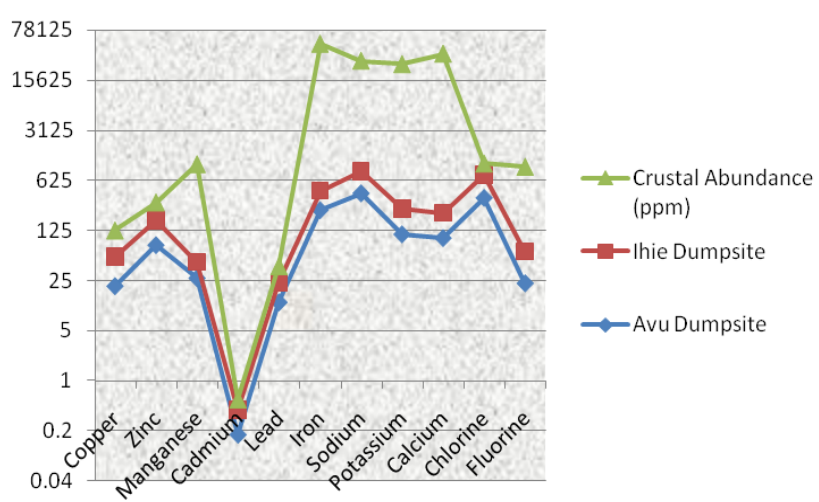

Figure 6. A graph of the concentration versus elements in (ppm)

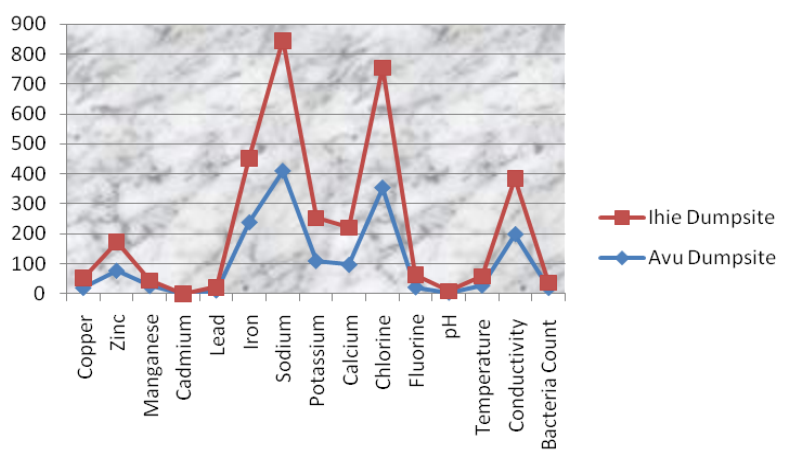

Figure 7. Graph of mean concentration of parameter analyzed at Avu and Ihie dumpsites

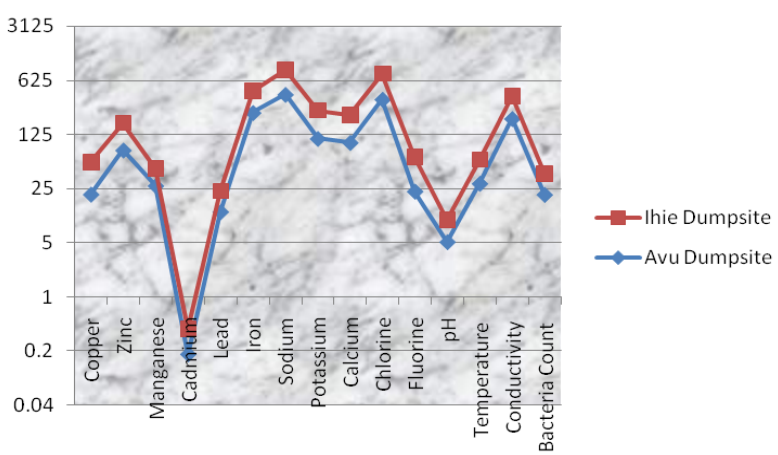

Figure 8. Correlation analyses of mean concentration of parameter analyzed from Avu and Thie dumpsites

Comparison was made with mean concentrations of the analyzed parameters and similar pattern of curves was displayed (Figures 7 and 8) like those obtained from sieve analysis (Figures 2 and 3). All the parameters analyzed exhibited a very strong positive correlation except cadmium that showed a negative correlation (Figures 6 and 8). These strong positive correlations evidenced by the similarity in graphs are signatures to the fact that similar wastes are been dumped at the two sites and the local geology and hydrogeology of the area are the same. It is interesting to note that the concentrations of soil samples collected far away from the dumpsites are lower compared the ones collected in the vicinity of the dumpsites. The enrichment of the soil by these elements may be due to its contact with leachate from the dumpsites. 


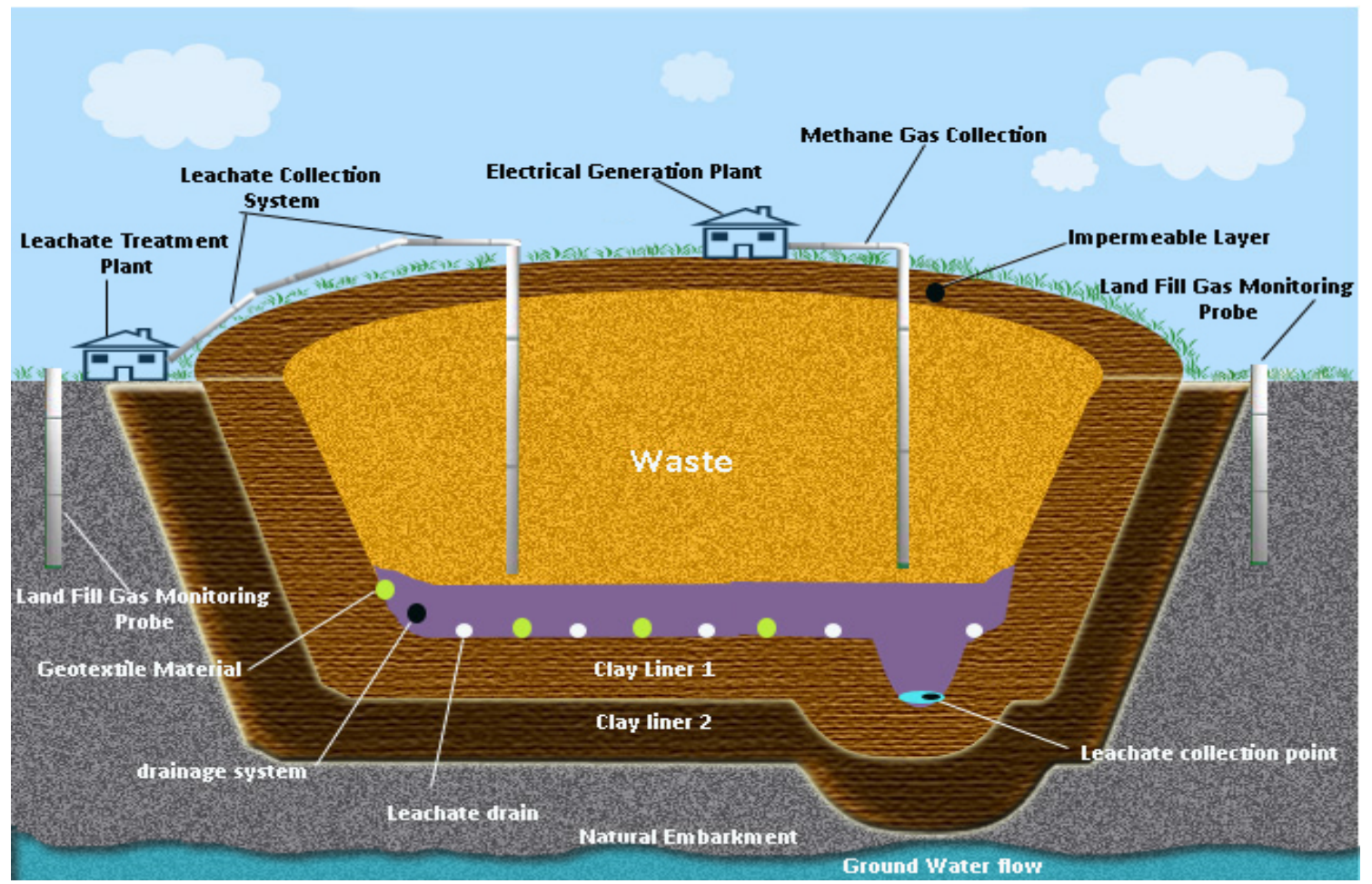

Figure 9. A modern sanitary landfill designed to replace Avu and Ihie open dumpsites

\section{Design of a Modern Sanitary Landfill for the Area}

Due to the indications of possible soil and aquifer contamination as a result of leachate migration the dumpsites, a modern sanitary landfill that encooperates the geomorphology, geology and hydrogeology of the area and offer protection to the soil and aquifer is illustrated in figure 9. The design incooperates two clay liners which are capable of impeding any downward movement of leachate into the soil and aquifer horizon. Leachates collected from the collection point are transported and treated at the treatment plant before been discharged. This helps in making dumpsite leachate harmless to the ecosysytem. Gas generated in the decomposition of wastes are channeled to generate electeri-city, a way of turning waste onto wealth.

\section{Conclusions}

From the study we have established that the two dumpsites are still in their active stage. The mean concentrations of manganese, lead, iron, $\mathrm{pH}$ and bacteria count were found to be higher in Avu dumpsite soil while the other parameters are higher at Ihie dumpsite soil. The concentration of all the parameters analyzed is far below the crustal abundance of the respective elements except cadmium. The high concentration of cadmium may be due to the decay of abandoned electric batteries and other electronic components on the dumpsites. The soil samples collected far away from the dumpsites have lower concentrations compared to those from the vicinity of the dumpsites. This is a signature that leachate from the waste dumps which are rich in heavy metal are interacting with the soil and thereby enriching it. The graphs of sieve and correlation analyses from the dumpsites were very similar and it implies similarity in wastes materials and geohistory. A modern sanitary landfill system that will protect the soil and aquifer from contamination was designed for the area. Construction of future dumpsites in the area should follow the prescribed design.

\section{REFERENCES}

[1] M. Banar, O. Aysun, K. Mine. Characterization of the leachate in an urban landfill by physicochemical analysis and solid phase microextraction. GC/MS. Environ. Monitor. Assess., 2006, 121: 439 - 459

[2] B. J. Alloway. Heavy metals in soil. John Wiley and sons Inc., New York, 1990 339p

[3] F. Tahri, M. Benya, E. I. Bounakla, J. J. Bilal. Multivariate analysis of heavy metal in soils, sediments and water in the region of Meknes, Central morocco. Environ. Monitor. Asses., 2005, 102: $405-417$

[4] Y. P. Lin, T. P. Teng, T. K. Chang. Multivariate analysis of soil heavy metal pollution and landscape in Changhua Country in Taiwan. Landscape Urban Plan., 2002, 62: 19 - 35

[5] A. N. Amadi, M. I. Ameh, and J. Jisa. The impact of dumpsites on groundwater quality in Markurdi Metropolis, Benue State. Natural and Applied Sciences Journal, 2010, 11(1): 90 $-102$

[6] A. K. Chopra, C. Pathak, G. Prasad. Scenario of heavy metal contamination in agricultural soil and its management. Jour- 
nal of Applied and Natural Sciences, 2009, 1: 99 - 108

[7] L. Bacud, F. Sioco, J. Majam. A descriptive study of the water quality of drinking wells around Payatas dumpsite, Unpublished BSc Thesis, University of the Philippines College of Public Health, 1994, 12 - 24

[8] J. A. Awomeso, A. M. Taiwo, A. M. Gbadebo, A. O. Arimoro. Waste disposal and pollution management in urban areas: A workabale remedy for the environment in developing countries. American Journal of Environmental Sciences, 2010, 6(1): $26-32$

[9] G. L. Sia Su. Assessing the effects of a dumpsite to groundwater quality in Payatas, Philippines. American Journal of Environmental Science, 2008, 4(4): 276 - 280

[10] H. I. Ezeigbo. Towards efficient water resources management in Nigeria. Water Resources, 1990, 2(1): 40 - 42

[11] A. A. Avbovbo. Tertiary Lithostratigraphy of Niger Delta. Bulletin of American Association Petroleum Geologist, 1978, 62: $297-306$

[12] A. C. Onyeagocha. Petrography and depositional environment of the Benin Formation, Nigerian Journal of Mining and Geology, 1980, 17: 147-151

[13] R. A. Reyment. Aspects of the geology of Nigeria, Ibadan University press, $1965,147 \mathrm{pp}$

[14] K. M. Ibe, A. H. O. Sowa, O. C. Osondu. Environmental contamination and other anthropogenic impacts on Otamiri and Nworie rivers in Owerri, Nigerian. Journal of Mining and Geology, 1992, 28 (1): 87 - 91

[15] K. O. Uma, B. C. E. Egboka. Water resource of Owerri and its environs, Imo State, Nigeria. Journal of Mining and Geology,
1985, 22(1\&2): $57-64$

[16] K. C. Short, A. J. Stauble. Outline of the geology of Niger Delta, American Association of Petroleum Geologists Bulletin, 1967, 51: 761-779

[17] USEPA. Test methods for evaluating solid waste. Physical/Chemical Methods. $3^{\text {rd }}$ Edn., Method 3050B, Acid Digestion of Sediment, Sludges and soils, USEPA, Washington, DC, 1996, SW-846

[18] D. Dineley, D. Hawkes, P. Hancock, B. Williams. Earth resources - A dictionary of terms and concepts, Arrow Books LTD, London, 1976, 205p

[19] K. O. Uma. Assessment of the impact of gas flaring on the quality of rain water, surface water and groundwater in parts of the oil producing region of Nigeria. Water Resources, 1989, 1(2): $200-204$

[20] A. N. Amadi. Assessing the Effects of Aladimma Dumpsite on Soil and Groundwater Using Water Quality Index and Factor Analysis. Australian Journal of Basic and Applied Sciences, 2011, 5(11): 763 - 770

[21] E.J. Mull. Approaches toward sustainable urban solid waste management: Sahakaranagar Layout, Unpublished M.Sc. thesis, Int. Environ. Sci., Lund University, Lund, Sweden, $2005,37 \mathrm{p}$

[22] M. N. Tijani. Bacteriological, chemical and lithologic control on the water quality in Sagamu area, Southwestern Nigeria. Water Resources, 2004, 15(2): $66-76$

[23] D. R. Odero, E. Semu, G. Kamau. Assessment of cottage industries-derived heavy metal pollution of soil within Ngara and Gikomba area of Nairobi city, Kenya. African Journal of Science and Technology, 2000, 1: $52-62$ 